\title{
Effect of high pressure homogenization on aqueous phase solvent extraction of lipids from Nannochloris Oculata microalgae
}

\author{
Nalin Samarasinghe, Sandun Fernando, Brock Faulkner \\ Department of Biological and Agricultural Engineering, Scoates Hall, TAMU, Texas A\&M University, College Station TX USA
}

Email address:

sfernando@tamu.edu (S. Fernando)

\section{To cite this article:}

Nalin Samarasinghe, Sandun Fernando, Brock Faulkner. Effect of High Pressure Homogenization on Aqueous Phase Solvent Extraction of Lipids from Nannochloris Oculata Microalgae. Journal of Energy and Natural Resources. Vol. 1, No. 1, 2012, pp. 1-7.

doi: 10.11648/j.jenr.20120101.11

\begin{abstract}
The ability to extract lipids from high-moisture Nannochloris Oculata algal biomass disrupted with high pressure homogenization was investigated. During the first phase, the effect of high pressure homogenization (system pressure and number of passes) on disrupting aqueous algae (of different concentrations and degree of stress) was investigated. Secondly, the effect of degree of cell wall disruption on the amount of lipids extracted with three solvents, namely: hexane, dichloromethane and chloroform, were compared. Studies reveled that high pressure homogenization is effective on cell disruption while the amount of system pressure being the most significant factor affecting the degree of cell breakage. Although the number of passes had some impact, the level of disruption seemed to level-off after a certain number of passes. The study revealed that slightly polar solvents (such as chloroform and dichloromethane) performed better in aqueousphase lipid extractions as compared to hexane. Also, it was revealed that it was not necessary to disrupt the algal cells completely to achieve appreciable levels of lipid yields. In fact, conditions that exerted only $20 \%$ of the cells to completely disrupt, allowed sufficient damage to liberate most of the lipids contained in the remainder of the cells.
\end{abstract}

Keywords: Microalgae, Homogenization, Extraction, Lipids

\section{Introduction}

Using micro-algal biomass constituents as substrates for fuel and chemicals production has attracted wide attention since algae can surpass lipid content and biomass production efficiency of lipogenic terrestrial plants[1-3]. However, there are several challenges that need to be overcome before algal based energy systemsbecome a sustainable reality. One such challenge is the inherentlyhigh moisture of algal growth medium (close to $99.9 \% \mathrm{w} / \mathrm{w}$ - wet basis) that needs to be removed prior to any sort of meaningful processing. Physical and chemical harvesting techniques such as sedimentation, flocculationor centrifugation can only reduce the amount of moisture to a level around $90 \%$ $(w / w)[4,5]$ and further removal of moisture can only be achieved via drying. Drying is energy intensive and removal of such magnitude of moisture is cost prohibitive - especially if reliable solar energy is not available[5-7]. The smaller size of microalgaeof the order of several micro$\mathrm{ns}[8]$ coupled with the presence of an intransigent cell wall
[9] thatrequires the cells to be ruptured [10] prior to product extraction, pose additional challenges for processing microalgae. Accordingly, a cell extraction technique, to be successful for algal biomassshould: 1)tolerate high moisture environment and 2) include some sort of cell-wall disruption step to allow the solvent access lipid containing cellular matrixes. This study looks at the effectiveness of extracting algal lipids in a high-moisture environment.

Previously, we have demonstrated that high pressure homogenization can be effectively used for rupturing algal cell walls [11]. In light of this, high pressure homogenization was selected as cell rupture mechanism for this study. Previous studies suggest hexane, chloroform, chloroform/alcohol mixtures, and alcohol to be effective in algal biomass that has approximately $<20 \%$ moisture [12-14]. Thus, hexane, chloroform and dichloromethane were used as extraction solvents. This study was directed toward finding the correlation between the degree of cell rupture and the effectiveness of aforementioned lipophilic solvents that are immiscible in water in extracting lipids. Accordingly, a 
two phase study was conducted. First, the effect of homogenization on algal cell-wall disruption was studied. Then, the amounts of lipids liberated from algae with various degrees of cell disruption to these solvents were analyzed.

\section{Materials and Methods}

Algal samples: Nanochloris oculata (N. oculata) algal cells (obtained from Texas Agrilife Research Algal Research facility, Pecos, Texas) were used for these studies. The samples contained "stressed algae" that were subjected to physiological stress via nitrogen depletion and those that were not subjected to nutrient depletion. Stressing of algae is known to increase the lipid content $[15,16]$.

The Total Suspended Solids (TSS) content of an algal broth obtained from a photo bioreactor or an open pond lies around $0.1 \%$ (wet weight basis) [5, 17-19]. However, the samples that were used for this study were preconcentrated at the growth facility to a TSS level of around $17 \%$ via centrifugation (for effective shipping).For the lipid extraction technology to be adoptable to a range of harvesting techniques, it was decided to reduce the TSS of algae to $10 \%$ via dilution with water. So, all the experiments presented used algae with $10 \%$ TSS starting algal concentration (or $90 \%$ moisture content wet weight basis) unless noted otherwise.

Homogenization: A NanoDeBEEbench-tophigh pressure homogenizer (Bee international, MA, USA) was used for homogenizing algal samples. The schematic representation of the cross section of the homogenizer is given in the Figure 1.

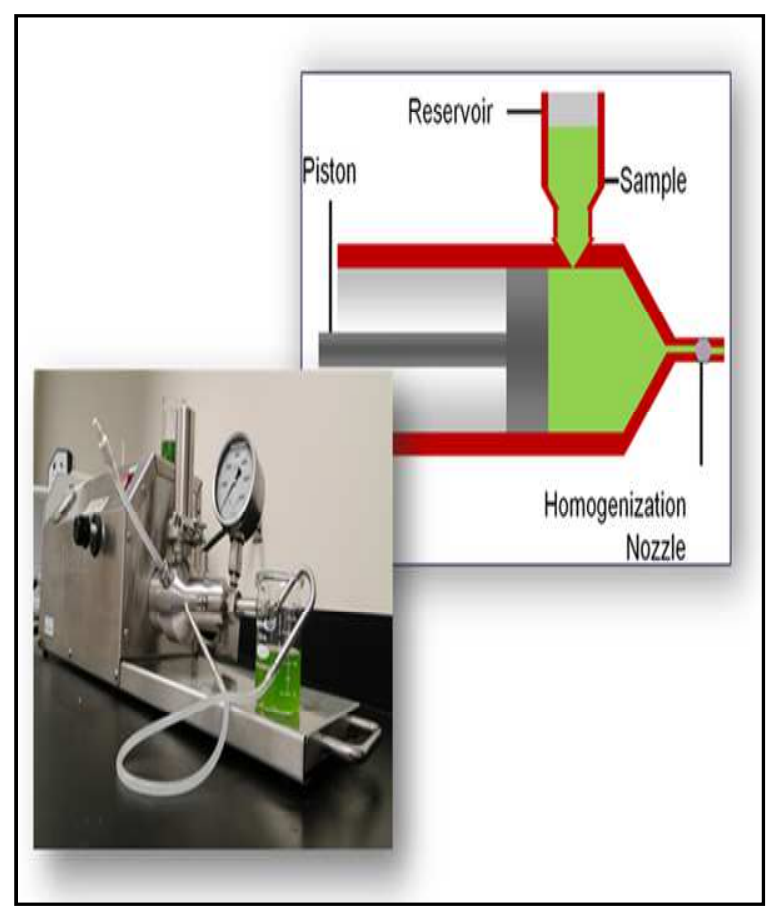

Figure 1. High pressure homogenizer used for the experiment.

The homogenizing scheme is as follows: Anaqueous (al- gal) sample is initially placed in the sample reservoir. A hydraulically operated piston siphons in the sample into the pressure cylinder through a non-return valve. Then, the reciprocating piston forces the sample through a nozzle orifice. As a result of the high shear forces and the sudden pressure drop across the nozzle, algal cells get rupturedduring the passage through the orifice.

\subsection{Effect of High Pressure Homogenization on The De- gree of Algal Cell Rupture}

A study was performed to assess the extent of cell-wall damage on N. oculataby homogenizationunder several variables. The parameters used in the study werepressure, number of passes, stress of the sample and the algal concentration. Levels of these variables are shown in Table 1. A full factorial design was utilized with three replicates at each design point.

Table 1. List of variables for determining effect of high pressure homogenization on N.oculata.

\begin{tabular}{lllll}
\hline Variable & $\begin{array}{l}\text { TSS } \\
\text { (w/w - wet basis) }\end{array}$ & Stress & $\begin{array}{l}\text { Pressure } \\
\text { (Psi) }\end{array}$ & $\begin{array}{l}\text { Number } \\
\text { of passes }\end{array}$ \\
\hline Levels & $\begin{array}{l}0.1 \% \\
(\text { Non- } \\
\text { Concentrated) } \\
1 \%\end{array}$ & $\begin{array}{l}\text { Non } \\
\text { Stressed }\end{array}$ & 10000 & 1 \\
& Stressed & 20000 & 2 \\
\hline
\end{tabular}

Cell Imaging and Counting: Disposable, Neubauer Improved C-Chip DHC-S01 semen counting chambers (Incyto, Chungnam-do, Korea), with $10 \mu$ l capacity were used for cell counting.

A Zeiss Axiphot optical microscope with 20x object resolution was used for imaging the cells in counting chambers. A black and white digital camera was used for capturing sections of the counting chamber separately as the entire counting grid was not able to be captured in one image using the required magnification. Image processing software "ImageJ1.42q"(National Institute of Health, USA) was used for counting cells in the images. The degree of cell breakage was characterized as a percentage of the total number of intact cells observed per unit volume. Double counting of cells in multiple images was avoided by cropping images along the gridline.

The intact cell percentage after homogenization (which inversely correlates to the degree of cell breakage) was calculated according to Equation 1:

$$
\begin{aligned}
& \% \text { Cells Remaining }= \\
& \frac{\text { Cell density in sample after treatment }}{\text { Cell density in sample before treatment }} \times 100 \%
\end{aligned}
$$

\subsection{Behavior of the Selected Extraction Solvents in Ex- tracting Partially Ruptured Algal Biomass}


Solvents Used: Three types of organic solvents were used;namely, hexane, dichloromethane and chloroform. Hexane was selected because it is the industry standard for extraction of lipids in the oleochemical industry. Chloroform was selected due to its slightly higher polarity as compared to hexane and based on prior work on algal oil extraction[11].It was hypothesized that moisture-laden algae would be more miscible/compatible with chloroform due to its slightly polar nature and ability to form hydrogen bonding. Dichloromethane was tested due to its higher miscibility with water, compared to chloroform. It should be noted that hexane and chloroform are considered nonpolar solvents while dichloromethane is a polar aprotic solvent and therefore dichloromethane demonstrate a higher miscibility with water compared to chloroform.

Extraction Procedure: Initially, $10 \mathrm{ml}$ of $10 \%$ (TSS) algae (in aqueous environment) were homogenized using a NanoDeBee High pressure homogenizer according to predetermined pressures and number of passes. There pressures and number of passes were selected based on the results from our previous studies[11] to give distinct, percentages of celldisruption. Subsequently, the homogenized algae wasvortexed with $10 \mathrm{ml}$ of solvent for 1 minute at 10 , $000 \mathrm{rpm}$. Then, the mixture was centrifuged at 10,000 rpm for 5 minutes to separate thesolvent phasefrom aqueous phase. Then, $7 \mathrm{ml}$ of solvent waspipetted into an $8 \mathrm{ml}$ high pressure reaction vial (VWR, PA, USA). Lipid exhausted algae and remaining solvent was mixed with an additional $10 \mathrm{ml}$ of solvent and centrifuged at $10000 \mathrm{rpm}$ for $5 \mathrm{mi}-$ nutes to obtain another extraction. This procedure was repeated to obtain three sequential extractions from a single algal sample. The solvent in the reaction vial was evaporated to obtain lipid-residue.

Transesterification: Transesterification was conducted according to the procedure depicted in Figure 2. First, the residue was dried in an oven at $105^{\circ} \mathrm{C}$ until the weight of the sample became constant to remove moisture. Then, $4 \mathrm{ml}$ of $4 \%$ methanolic $\mathrm{H}_{2} \mathrm{SO}_{4}$ (the transesterification catalyst) and $1 \mathrm{ml}$ of $0.75 \mathrm{mg} / \mathrm{ml}$ methanolic C15 Fatty Acid (transesterification internal standard (ISTD)), was added to the dried residue.The purpose of transesterification ISTD is to calculate the transesterification efficiency as described later This mixture was reacted at $110^{\circ} \mathrm{Cfor} 2$ hours while vortexing for 20 seconds at 15 minute intervalsat $10,000 \mathrm{rpm}$. After 2 hours of reaction, the sample was mixed with $3 \mathrm{ml}$ of hexane and $4 \mathrm{ml}$ of water and vortexed for 1 minute at 10,000 rpm to transfer Fatty Acid Methyl Esters (FAMEs) to hexane layer. After vortexing, the sample was centrifuged at 2,500 rpmfor 5 minutes to separate the hexane layer. The hexane layer was pipetted out and filtered using a $0.2 \mu \mathrm{m}$ PTFE syringe filter. $1 \mathrm{ml}$ of this sample was transferred to a $2 \mathrm{ml} \mathrm{GC}$ auto sampler vial and $50 \mu \mathrm{l}$ of $1 \mathrm{mg} / \mathrm{ml} \mathrm{C13} \mathrm{-} \mathrm{C19} \mathrm{fatty} \mathrm{acid} \mathrm{methyl} \mathrm{esters} \mathrm{(FAME)} \mathrm{in} \mathrm{hex-}$ ane mixture was added as the GC internal standard. This sample evaluated for FAME concentration via GC equipped with a flame ionization detector (FID) (6890 GC,
Agilent Technologies, Inc., CA, USA-6850 series with a 30 meter DB-WAX column).

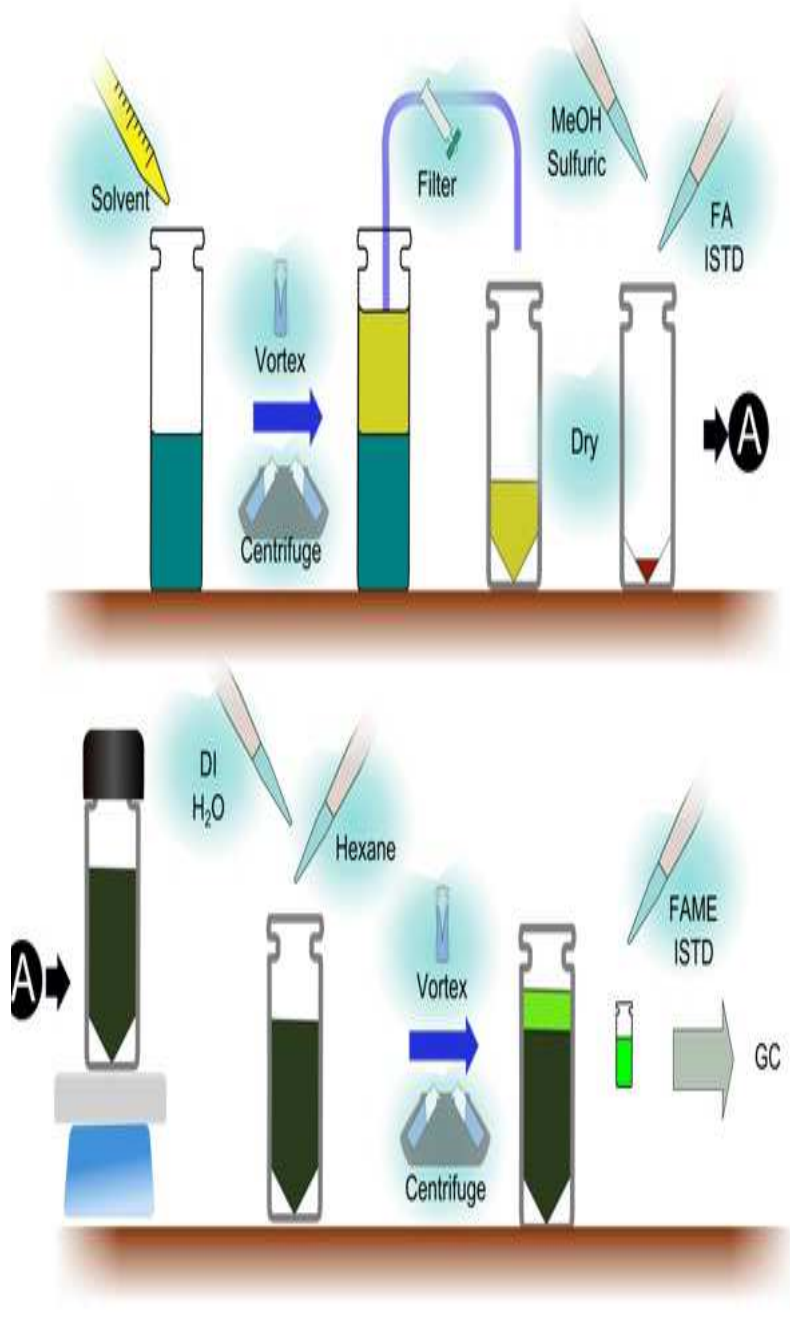

Figure 2. Extraction methodology.

In the GC analysis, the area under the signal for each peak of the FID signal was calculated and the resulting area was compared with the signal obtained for the 5\% standard FAME mixture(Nu-Chek Prep, Inc. MN, USA - catalog number 68A)in hexane to obtain the total amount of FAMEs in the transesterified sample. Since the amount of C15 fatty acidmixed with the lipid sample and the amount of C15 FAME in transesterified sample is known, it is possible to determine the efficiency of the transesterification. Using the amount of total fatty acid methyl esters and transesterification efficiency, it is possible to calculate the amount of FAs available in the original sample.

Experimental Design: A full factorial design was utilized with extent of cell disruptionand solvent type as independent variables. Table 2 shows the entire distribution of the variables used. An asterisk (*) represents a single design point. Three replicates were performed on each design point.

Design Expert 8 statistical analyzing software package 
from Stat-Ease, Inc, MN was used for the analysis of results. In this particular segment of studies,a square-root transformation was used to obtain a proper normal distribution.

Table 2. Experimental design for determining the behavior of the selected extraction solvents in extracting partially ruptured algal biomass.

\begin{tabular}{|c|c|c|c|c|c|c|c|c|c|c|c|}
\hline \multirow{4}{*}{ Pressure } & \multirow{4}{*}{ Number of passes } & \multirow{4}{*}{ Cell Disruption } & \multicolumn{9}{|l|}{ Solvent } \\
\hline & & & \multicolumn{3}{|l|}{ Hexane } & \multicolumn{3}{|c|}{ Dichloromethane } & \multicolumn{3}{|c|}{ Chloroform } \\
\hline & & & \multicolumn{3}{|c|}{ Extraction No. } & \multicolumn{3}{|c|}{ Extraction No. } & \multicolumn{3}{|c|}{ Extraction No. } \\
\hline & & & 1 & 2 & 3 & 1 & 2 & 3 & 1 & 2 & 3 \\
\hline $\mathrm{N} / \mathrm{A}$ & N/A & Non Treated & $*$ & $*$ & $*$ & $*$ & $*$ & $*$ & $*$ & $*$ & * \\
\hline 10000 & 2 & $10 \%$ & $*$ & $*$ & $*$ & * & $*$ & $*$ & $*$ & $*$ & * \\
\hline 20000 & 2 & $20 \%$ & $*$ & $*$ & $*$ & $*$ & $*$ & $*$ & $*$ & $*$ & * \\
\hline 30000 & 3 & $54 \%$ & $*$ & $*$ & $*$ & * & $*$ & $*$ & $*$ & $*$ & * \\
\hline 40000 & 4 & $67 \%$ & $*$ & $*$ & $*$ & * & $*$ & $*$ & $*$ & $*$ & * \\
\hline
\end{tabular}

\section{Results and Discussion}

\subsection{Effect of High Pressure Homogenization on The De- gree of Algal Cell Rupture}

Two microscopicimages of algal samples before and after homogenization are shown in Figure 3. It is apparent that the number of intact cellshas reduced in the solution matrix (right picture)with increasing pressure treatment (as compared to the left picture). This is because ruptured cell particles are smaller than the resolution selected to image the intact cells.

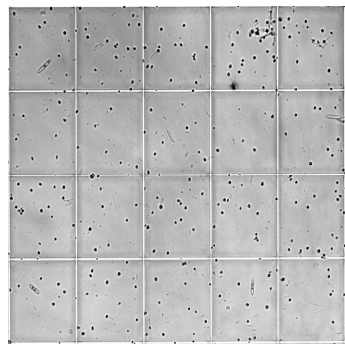

(a)

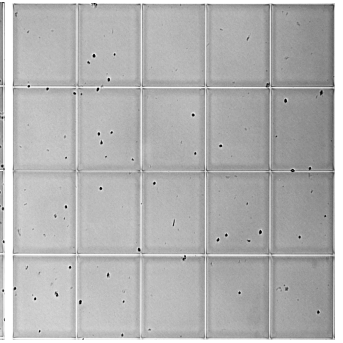

(b)
Figure 3. (a) Stressed non-homogenized algae; (b) homogenized using Z8 (195 $\mathrm{mm}$ ) Nozzle, 2 passes, 40000 PSI (103.421 MPa) (Sample concentration is $0.1 \%$.).

Results of an analysis of variance (ANOVA) from homogenization studies are depicted in Table 3. According to the analysis, it is clear that all of the variables are statistically significant.

Table 3.ANOVA table of homogenization of N. Oculata [Classical sum of squares - Type II].

\begin{tabular}{llllll}
\hline Source & $\begin{array}{l}\text { Sum } \\
\text { of Squares }\end{array}$ & df & $\begin{array}{l}\text { Mean } \\
\text { Square }\end{array}$ & F Value & $\begin{array}{l}\text { p-value } \\
\text { (Prob>F) }\end{array}$ \\
\hline Block & 228.95 & 2 & 114.48 & & \\
Model & 73539.41 & 8 & 9192.43 & 75.55 & \\
$\quad$ A-Concentration & 10118.49 & 1 & 10118.49 & 86.16 & $<0.0001$ \\
B-Extentof Stress & 551.66 & 1 & 551.66 & 4.53 & $<0.0001$ \\
$\quad$ C-Press & 45837.27 & 3 & 15279.09 & 125.58 & $<0.0001$ \\
$\quad$ D-Number of & 17032 & 3 & 5677.33 & 46.66 & $<0.0001$ \\
$\quad \begin{array}{l}\text { Passes } \\
\text { Residual }\end{array}$ & 22022.02 & 181 & 121.67 & & \\
Corr. Total & 95790.38 & 191 & & & \\
\hline
\end{tabular}

\subsection{Behavior of the Selected Extraction Solvents in Ex- tracting Partially Ruptured Algal Biomass}

Statistical analysis was utilized to ascertain whether the variables used, i.e., level of cell disruption and the type of solvent, had any significant impact on the amount of extractable lipids. According to the ANOVA (Table 4), it is clear that all of the variables in fact affected the response variable.

Table 4. ANOVA table for solvent extraction of algal lipids from homogenized N. oculata.[Classical sum of squares - Type II].

\begin{tabular}{llllll}
\hline Source & $\begin{array}{l}\text { Sum } \\
\text { of Squares }\end{array}$ & df & $\begin{array}{l}\text { Mean } \\
\text { Square }\end{array}$ & F Value & $\begin{array}{l}\text { p-value } \\
\text { (Prob>F) }\end{array}$ \\
\hline Block & 0.025 & 2 & 0.014 & & \\
Model & 18.99 & 8 & 2.37 & 103.53 & $<0.001$ \\
A-Solvent & 0.73 & 2 & 0.37 & 16.01 & $<0.001$ \\
B-Disruption & 4.56 & 4 & 1.15 & 50.09 & $<0.001$ \\
C-Extraction & 12.58 & 2 & 6.28 & 273.86 & $<0.001$ \\
Residual & 2.48 & 108 & 0.023 & & \\
Corr. Total & 21.49 & 118 & & & \\
\hline
\end{tabular}

Diagnostic plots (not illustrated) were utilized to confirm the statistical viability of the experimental design. According to Figure 5, it is clear that the amount of lipids extracted reduced with each extraction iteration $(\mathrm{R} 2>0.95)$. The highest amount of lipids extracted was $48.15 \mathrm{mg}$ of FA from $1 \mathrm{~g}$ of algae (Dry basis) with chloroform in the first extraction. In this instance, the third extraction resulted in only $5.7 \mathrm{mg}$ of FAs from $1 \mathrm{~g}$ of algal lipids. Although the solvents behaved differently for the initial extraction, they behaved very similar during subsequent extractions.

Figure 4 depicts the variation of percentage of intact cells remaining in the sample after subjecting to various combinations homogenization treatments. It is clear that a higher number of passes and highpressure resulted in a higher level of cell disruption. Although the level of cell disruption seemed to correlate highly with the pressure of the homogenizer, the effect of the number of passes seemed to level off. This may be attributed to physiochemical properties of cell walls that do not respond effectively to repeated exposure of algae to shear (under the same pressure). Nevertheless, the effect of pressure was more profound - algal cells disrupted increasingly with increased pressure. It should be noted that some remaining cell frac- 
tion values were higher than $100 \%$. This happens as a result of breakage of the cell conglomerates without significant disruption of cells during low intensity homogenization.

The effects of the degree of cell disruption and the extraction solvent on the lipid yields are depicted in Figure 6. The degree of cell disruption significantly affects the efficiency of lipid extraction. However, the effect tends to level off after about $20 \%$ cell disruption. Disrupting cells beyond this level seems not to be necessarily advantageous. This is important in a sense that total disruption of algal cells incurs significantly higher energy costs and is not needed. This tapering effect was more pronounced for hexane as compared to chloroform and dichloromethane. For hexane, the increase of lipid extraction efficiency seemed to level off at as low as $10 \%$ cell disruption. It is conjec-

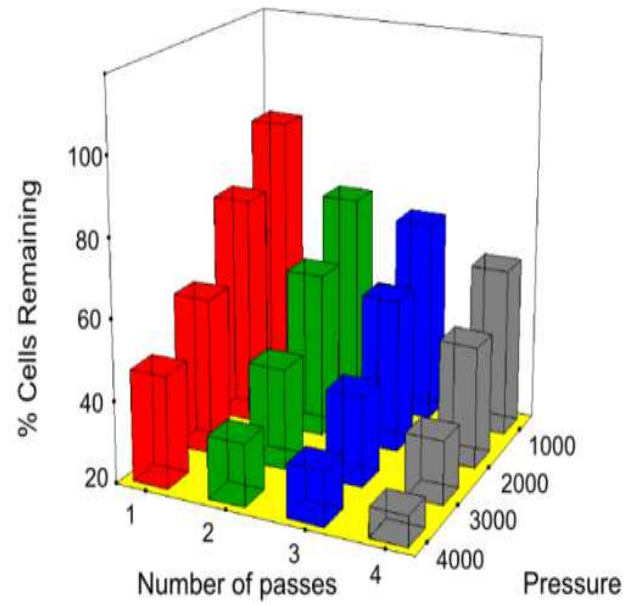

(a)

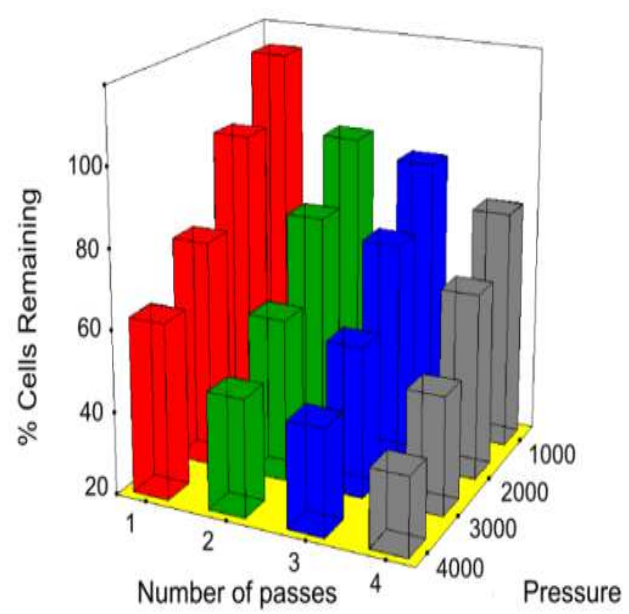

(c) tured that at $10 \%$ disruption, most of the cell walls are adequately damaged for the extraction solvents to penetrate into the cell for dissolving lipids. Further homogenization, though disintegrate damaged cells, does not seem to assist in releasing additional lipids. The higher effectiveness of dichloromethane and chloroform, compared to hexane specially observed in lower percentage cell disruptions may be attributed to higher compatibility of dichloromethane and chloroform with the polar cell wall. It was noted that highly disrupted algae (when at least $67 \%$ of the cells are broken), when extracted with any solvent, results in almost 8.5 times more oil than undisrupted algae. However, when the cells were disrupted, the differences between the total amounts of lipids extracted (total accumulation after consecutive extractions) were minimal.

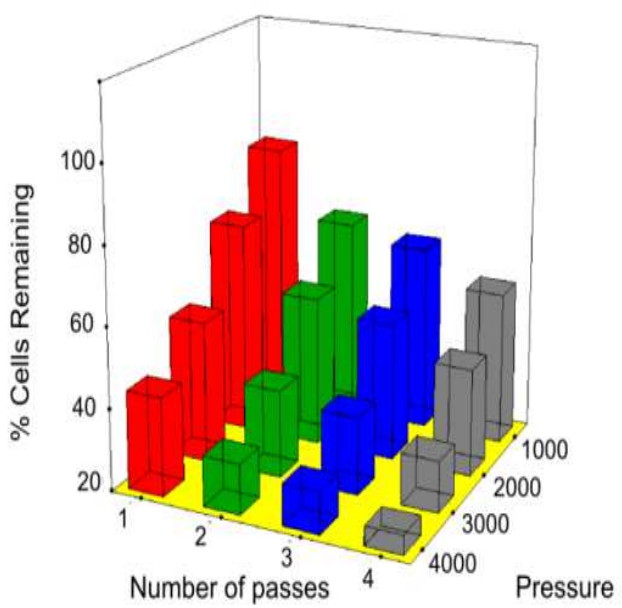

(b)

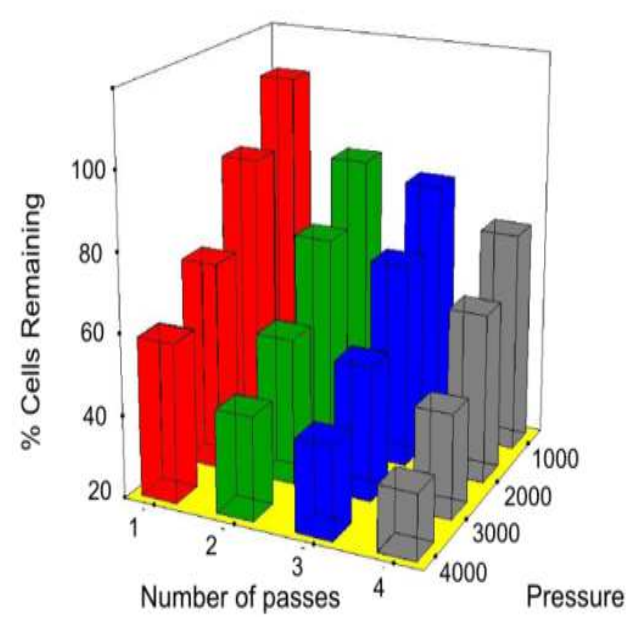

(d)

Figure 4. Percentage of whole cells remaining after homogenization (a) $0.1 \%$ concentration, unstressed; (b) $0.1 \%$ concentration, stressed; (c) $1 \%$ concentration, unstressed; (d) 1\% concentration, stressed. 


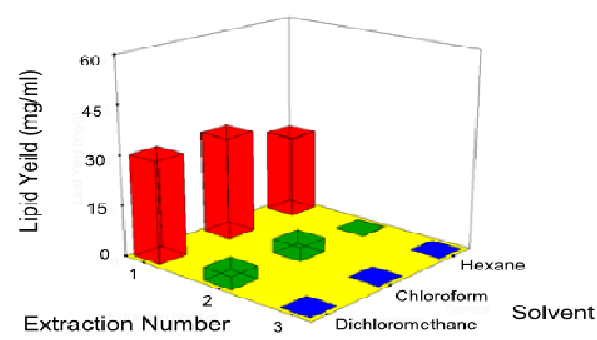

(a)

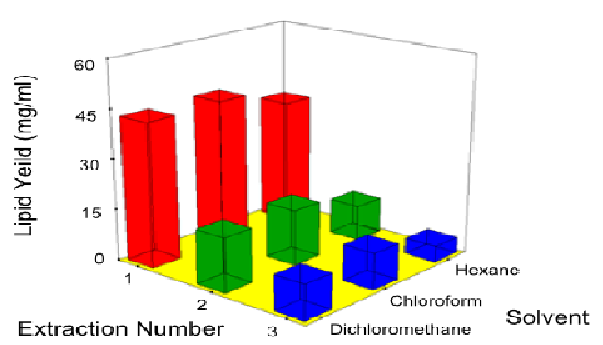

(c)

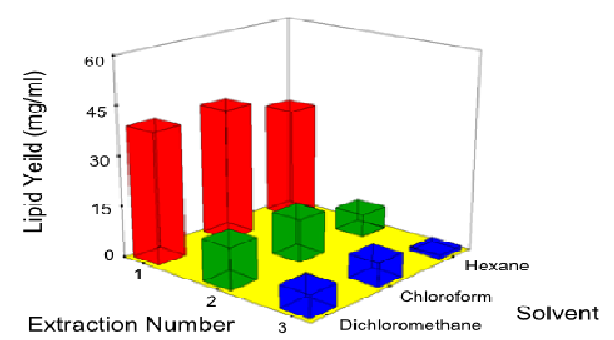

(b)

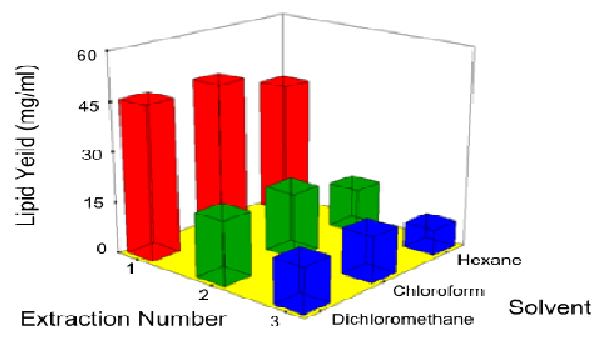

(d)

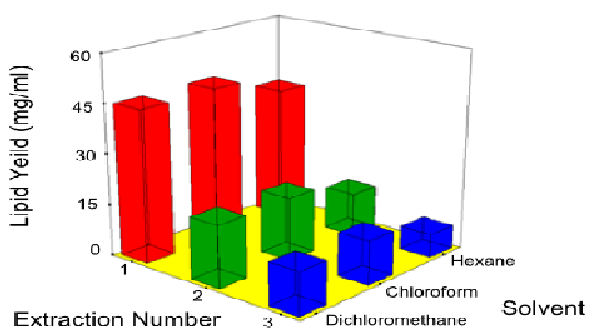

(e)

Figure 5. Variation of amount of lipids extracted when different amounts of cells are disrupted. (a) $0 \%$ cell disruption; (b) $10 \%$ cell disruption; (c) $20 \%$ cell disruption; (d) $54 \%$ cell disruption; and (e) $67 \%$ cell disruption.

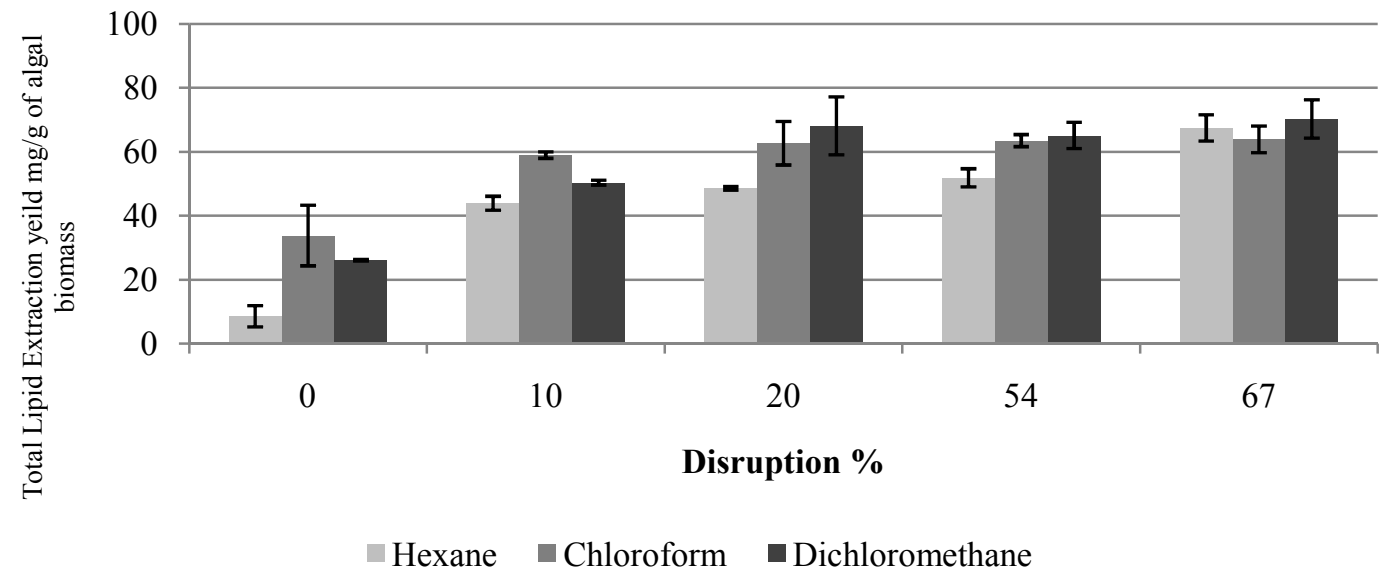

Figure 6. Lipids extracted from 1 gram of biomass during three consecutive extractions.

The effects of the degree of cell disruption and the extraction solvent on the lipid yields are depicted in Figure 6. The degree of cell disruption significantly affects the efficiency of lipid extraction. However, the effect tends to level off after about $20 \%$ cell disruption. Disrupting cells beyond this level seems not to be necessarily advantageous. This tapering effect was more pronounced for hexane as compared to chloroform and dichloromethane. For hexane, the increase of lipid extraction efficiency seemed to level off at as low as $10 \%$ cell disruption. It is conjectured that at $10 \%$ disruption, most of the cell walls are adequately damaged for the extraction solvents to penetrate into the cell for dissolving lipids. Further homogenization, though disintegrate damaged cells, does not seem to assist in releasing 
additional lipids.

The higher effectiveness of dichloromethane and chloroform, compared to hexane may be attributed to higher compatibility of dichloromethane and chloroform with the polar cell wall. It was noted that highly disrupted algae (when at least $67 \%$ of the cells are broken), when extracted with any solvent, results in almost 8.5 times more oil than undisrupted algae. However, when the cells were disrupted, the differences between the total amounts of lipids extracted (total accumulation after consecutive extractions) were minimal.

\section{Conclusions}

The study confirms that aqueous phase extraction of algal lipids is possible from algal biomass of only $10 \%$ TSS (or $90 \%$ moisture $\mathrm{w} / \mathrm{w}$ - wet basis) using hexane chloroform and dichloromethane. It is clear from the analysis that the degree of cell disruption significantly affects the amount of lipids that can be extracted. The study clearly established the fact that although some form of cell disruption is necessary to obtain appreciable oil yields, it is not necessary to totally disintegrate algal cell walls to extract appreciable amount of lipids. Although the amount of lipid extracted increased with increasing level of cell disruption, the increase of lipid yield leveled off after $20 \%$ cell disruption.

During the three consecutive extractions, irrespective of the type of solvent used, the second and the third extraction reduced in the amount of lipid yields -approximately to $21 \%$ and $11 \%$ from the total. Even though chloroform and dichloromethane were more effective in the first extraction, when lipids extracted from all three iterations are considered, hexane trailed behind only slightly. The slight polarity of chloroform and dichloromethane (as compared to hexane) seemed to assist in initial extractions - likely due to the compatibility of these solvents with the polar algal cell walls.

\section{References}

[1] Rakesh Agrawal, N.R.S., Fabio H. Ribeiro, W. Nicholas Delgass, Sustainable fuel for the transportation sector. PNAS, 2007. 104(12): p. 4828-4833.

[2] Ross, A.B., et al., Investigation of the pyrolysis behaviour of brown algae before and after pre-treatment using PYGC/MS and TGA. Journal of Analytical and Applied Pyrolysis, 2009. 85(1-2): p. 3-10.

[3] Beer, L.L., et al., Engineering algae for biohydrogen and biofuel production. Current Opinion in Biotechnology, 2009. 20(3): p. 264-271.

[4] Minowa, T., et al., Oil production from algal cells of Dunaliella tertiolecta by direct thermochemical liquefaction. Fuel,
1995. 74(12): p. 1735-1738.

[5] Molina Grima, E., et al., Recovery of microalgal biomass and metabolites: process options and economics. Biotechnology Advances, 2003. 20(7-8): p. 491-515.

[6] Sheehan, J., et al., Look Back at the U.S. Department of Energy's Aquatic Species Program: Biodiesel from Algae; Close-Out Report, 1998.

[7] Golueke, C.G. and W.J. Oswald, Harvesting and Processing Sewage-Grown Planktonic Algae. Journal (Water Pollution Control Federation), 1965. 37(4): p. 471-498.

[8] Slocombe, S.P., et al., A rapid and general method for measurement of protein in micro-algal biomass. Bioresource Technology, 2013. 129(0): p. 51-57.

[9] Sukenik, A., O. Zmora, and Y. Carmeli, Biochemical quality of marine unicellular algae with special emphasis on lipid composition. II. Nannochloropsis sp. Aquaculture, 1993. 117(3-4): p. 313-326.

[10] Mendes-Pinto, M.M., et al., Evaluation of different cell disruption processes on encysted cells of Haematococcus pluvialis: effects on astaxanthin recovery and implications for bio-availability. Journal of Applied Phycology, 2001. 13(1): p. 19-24.

[11] Samarasinghe, N., et al., Algal cell rupture using high pressure homogenization as a prelude to oil extraction. Renewable Energy, 2012. 48(0): p. 300-308.

[12] Chi-Sheng Wu, J. and E.-H. Lee, Ultrafiltration of soybean oil/hexane extract by porous ceramic membranes. Journal of Membrane Science, 1999. 154(2): p. 251-259.

[13] Sathish, A. and R.C. Sims, Biodiesel from mixed culture algae via a wet lipid extraction procedure. Bioresource Technology, 2012. 118(0): p. 643-647.

[14] Cheng, C.-H., et al., Comparative study of lipid extraction from microalgae by organic solvent and supercritical $\mathrm{CO} 2$. Bioresource Technology, 2011. 102(21): p. 10151-10153.

[15] Chisti, Y., Biodiesel from microalgae. Biotechnology Advances, 2007. 25(3): p. 294-306.

[16] Sheehan, J., et al., Look back at the U.S. Department of Energy's aquatic species program: biodiesel from algae; close-out report, 1998.

[17] Tredici, M.R. and R. Materassi, From open ponds to vertical alveolar panels - the italian experience in the development of reactors for the mass cultivation of phototrophic microorganisms. Journal of Applied Phycology, 1992. 4(3): p. 221-231.

[18] Levin, G.V., et al., Harvesting of algae by froth flotation. Applied and Environmental Microbiology, 1962. 10(2): p. 169-175.

[19] Crowe, B., et al., A Comparison of Nannochloropsis salina Growth Performance in Two Outdoor Pond Designs: Conventional Raceways versus the ARID Pond with Superior Temperature Management. International Journal of Chemical Engineering, 2012. 2012: p. 9. 